\title{
Pola Kepemimpinan Kepala Madrasah Aliyah Negeri Kisaran dalam Pelaksanaan Pekerjaan di Kabupaten Asahan
}

\section{Leadership Pattern of Madrasah Aliyah Negeri Kisaran Leader in Implementation of Work in Asahan Regency}

\author{
Qurrota A'yuni ${ }^{1}$ \\ 1 Program Studi Magister Administrasi Publik Universitas Medan Area, Indonesia. \\ *corresponding author: email : ayuniqurrota@yahoo.com
}

\begin{abstract}
Abstrak
Penelitian ini bertujuan untuk mengetahui dan menganalisis pola kepemimpinan Kepala MAN Kisaran dalam melaksanakan pekerjaan, pendelegasian wewenang dan koordinasi kerja di Kabupaten Asahan. Metode penelitian ini menggunakan metode penelitian deskriptif kualitatif. Dengan teknik pengumpulan data melalui, wawancara, observasi dan dokumen terhadap informan kunci yang dianggap benar-benar dapat memberikan informasi mengenai orang, peristiwa atau hal dengan tidak mementingkan jumlah informan tetapi lebih mementingkan bagaimana relevansinya dan ketepatannya dengan penelitian dilakukan. Hasil penelitian ini menunjukkan bahwa pola kepemimpinan Kepala MAN Kisaran dalam melaksanakan pekerjaan secara demokratif dan patisipatif, artinya perilaku pimpinan tersebut tidak otoriter, mau menerima masukan dari pegawainya, mengajak berdiskusi dan membuat keputusan secara musyawarah, kemudian dalam pelaksanaan pendelegasian wewenang telah berjalan sebagaimana mestinya, pembagian tugas dan kerja pegawai tersebut dilakukan secara adil, tidak diskriminatif dan membagi tugasnya sesuai dengan bidang masing-masing Dalam hal koordinasi kerja terjalin cukup baik, secara vertikal hubungan kerja Kepala MAN Kisaran dengan Kepala Seksi Pendidikan Madrasah Kabupaten Asahan terjalin hubungan kerjasama yang baik, terintegrasi dan terpadu, secara horizontal Kepala MAN Kisaran selalu aktif memberikan informasi terbaru dan mensosialisasikan kepada wakil, guru dan pegawai di dalam rapat internal.
\end{abstract}

Kata Kunci :Pola Kepemimpinan, Kepala, Pekerjaan.

\begin{abstract}
This study aims to determine and analyze the leadership patterns of the Head of MAN Kisaran in carrying out the work, delegation of authority and coordination of work in the District Asahan. This research method using descriptive qualitative research method. With data collection techniques through, interviews, observations and documents on key informants who are considered to be really able to provide information about people, events or things with no importance of the number of informants but more concerned with how its relevance and accuracy with research conducted. The results of this study indicate that the leadership pattern of the Head of MAN Kisaran in carrying out the work in a democratic and patisipatif, meaning the leadership behavior is not authoritarian, willing to receive input from employees, invites discussion and make decisions by deliberation, then in the implementation of delegation of authority has been running as it should, duties and employment of employees are done fairly, not discriminatory and divide their duties in accordance with their respective fields In terms of work coordination is well enough, vertically working relationship Head of Kisaran with Head of Education Section Madrasah Asahan School established a good cooperation, integrated and integrated, horizontally Head of MAN Kisaran always actively provide the latest information and socialize to the representatives, teachers and employees in the internal meeting.
\end{abstract}

Keywords: Pattern of Leadership, Head, Work.

How to Cite: A'yuni, Q., (2016), Pola Kepemimpinan Kepala Madrasah Aliyah Negeri Kisaran dalam Pelaksanaan Pekerjaan di Kabupaten Asahan, Jurnal Administrasi Publik, 7 (1): 64-76 


\section{PENDAHULUAN}

Kepala Madrasah adalah unsur pelaksana administrasi dengan tugas dan tanggung jawab menjalankan kegiatan administrasi sehari-hari. Dengan tidak mengecilkan arti keterlibatan komponen yang lain, pegawai merupakan komponen yang paling penting dalam tercapainya tujuan organisasi.

Dalam melaksanakan tugas Kepala Madrasah harus memiliki rasa tanggung jawab dan dedikasi yang tinggi sehingga pekerjaan yang dilakukan dapat mencapai keberhasilan yang maksimal. Keberhasilan tugas yang maksimal sesungguhnya dipengaruhi oleh penyelenggaraan administrasi yang efektif pula, hal ini senada dengan pendapat Sutisna (1987:56) yang menyatakan bahwa administrasi yang efektif memainkan peranan yang sangat menentukan dalam struktur dan artikulasi sistem organisasi. Penyelenggaraan administrasi yang efektif dalam pekerjaan sesungguhnya memerlukan penataan yang tepat mengenai pekerjaan yang diselenggarakan.

Madrasah Aliyah Negeri (MAN) Kisaran di Kabupaten Asahan sebagai sebuah organisasi tentunya memiliki kumpulan kegiatan yang sifatnya masih garis besar dan dalam pelaksanaan harus dijabarkan lebih lanjut sehingga dapat dilaksanakan secara operasional melalui prosedur kerja. Prosedur kerja merupakan kegiatan yang harus dilakukan secara berurutan untuk menyelesaikan suatu pekerjaan tertentu, dan dalam organisasi seperti halnya Madrasah Aliyah Negeri (MAN) Kisaran ini, rangkaian pekerjaan yang dimaksud bukan hanya sebatas tata cara persuratan, dan pengetikan, akan tetapi prosedur kerja diarahkan pada langkah- langkah dan aturan dalam penyelenggaraan kerja diantara unit kerja yang ada guna mencapai penyelesaian kerja yang tepat sasaran dan sesuai dengan harapan dari pekerjaan yang dilaksanakan.

Pelaksanaan pekerjaan dalam organisasi juga memiliki keterkaitan dengan koordinasi dan pendelegasian. Realitas prosedur kerja, koordinasi dan pendelegasian wewenang yang berlangsung di MAN Kisaran dalam kaitannya dengan pelaksanaan pekerjaan, namun timbul berbagai permasalahan di antaranya pegawai bekerja tidak berdasarkan pada rencana kerja yang telah dibuat, ditemukannya pegawai yang bekerja menunggu perintah, tidak ada inisiatif dan cenderung menumpuk pekerjaan, pegawai tidak dapat mengerjakan pekerjaan berdasarkan tugas maupun tanggung jawab yang telah dibebankan.

Berkaitan dengan hal di atas penting sekali menata pekerjaan, sehingga pegawai menjadi senang akan pekerjaannya. Hal ini memerlukan kerangka pekerjaan yang tepat dalam arti isi, fungsi, dan hubungannya. Dalam lingkup organisasi seperti MAN Kisaran di Kabupaten Asahan ini, maka penataan kerja sebagaimana dikemukakan di atas sesungguhnya menjadi tanggung jawab dari pemimpin. Seorang manajer atau pemimpin di harapkan memiliki suatu seni tentang bagaimana memimpin bawahan, mendayaguna bawahan, dan mengendalikan serta mengarahkan bawahan beserta seluruh unsur organisasi dengan sebaik-baiknya. Termasuk di dalamnya adalah mengembangkan kemampuan eksekutif bawahan agar mereka mampu mandiri dalam menyelesaikan tugas dan kewajibannya. Keberhasilan manajemen pada sebuah 
organisasi didasarkan pada peranan seorang pemimpin dan merupakan penjabaran serangkaian fungsi kepemimpinannya. Kepemimpinan itu sendiri sesungguhnya merupakan salah satu peran manajer dalam memberikan pengaruhnya kepada semua anggota agar dengan penuh kemauan memberikan pengabdian dalam mencapai tujuan organisasi sesuai kemampuan para bawahan secara maksimal.

Pengertian kepemimpinan bersifat universal, berlaku dan terdapat pada berbagai bidang kehidupan manusia, kepemimpinan merupakan proses mempengaruhi orang lain untuk mencapai suatu tujuan. Kepemimpinan tidak hanya ada pada organisasi akan tetapi dimana proses mempengaruhi orang lain ini berlangsung sudah dikatakan dengan kepemimpinan. Menurut Hall (1982:59) hakikat kepemimpinan banyak dibicarakan pakar administrasi dan organisasi karena dalam situasi tertentu kepemimpinan dirasakan penting, bahkan amat penting (critical). Menurut Stogdil (1974:123) pembicaraan tentang kepemimpinan pun cenderung bersifat subyektif, tergantung pada siapa yang membicarakan dan dari aspek mana kepemimpinan itu dikaji.

Locke (1997:45), mengemukakan bahwa "kepemimpinan sebagai proses mengajak (inducing) orang lain untuk mengambil langkah menuju suatu sasaran bersama". Koontz (1976:132) mengemukakan bahwa "Leadership is influencing people to follow individu at achievement of a common goal".

Kutipan di atas menekankan adanya upaya seseorang atau kelompok ke arah pencapaian tujuan kelompok. Demikian pula halnya dengan rumusan kepemimpinan dari Sutisna (1983:23), yaitu "kepemimpinan sebagai suatu proses mempengaruhi kegiatan seseorang atau kelompok dalam usaha kearah pencapaian tujuan dalam situasi tertentu".

Berdasarkan hal di atas perilaku pimpinan yang utama ialah membujuk (incuding) atau mempengaruhi (influencing) para anggota untuk bertindak dengan berbagai cara. Ia selalu tampil sebagai model (teladan) bagi para pengikutnya. Seorang pemimpin tidak akan berarti apa-apa jika tidak ada pengikut atau anggota. Inilah yang ditegaskan oleh Kouzes dan Posner (1993:56) bahwa "There is no Leadership without someone following".

Perilaku pimpinan merupakan tingkah laku seorang pimpinan dalam menjalankan peranan kepemimpinannya pada suatu organisasi dimana terjadi interaksi antara individu atau antara pimpinan dan karyawan. Perilaku tersebut memberi sifat kepada pendekatan pimpinan dalam memimpin orang / karyawan. Menurut Robbins (2002:2) perilaku organisasi adalah studi sistimatis tentang tindakan dan sikap yang ditunjukan oleh orang-orang dalam organisasi. Berdasarkan pendapat Robbins tersebut jelas bahwa individu yang berinteraksi satu dengan yang lain dalam bertindak dan bersikap, dengan adanya interaksi atau hubungan antar individu dalam organisasi, maka penelaahan terhadap perilaku organisasi harus dilakukan melalui pendekatan sumber daya manusia. Menurut Hersey ada 4 perilaku pimpinan yakni: perilaku memberitahukan (telling), perilaku menjual (selling), perilaku berperan serta (partisipatif), perilaku mendelegasikan (delegating). 
Reeser, dkk (1973:75) menjelaskan bahwa koordinasi adalah suatu fungsi yang menjamin sumbangan dari satu sub sistem atau bagian dalam organisasi dibuat sebagai syarat yang mana mereka saling terkait bersama ke dalam suatu situasi yang harmonis secara utuh. Selanjutnya koordinasi menurut Anderson (1984) bahwa koordinasi merupakan proses yang melibatkan pemindahan informasi antara pekerjaan dan orang untuk menghindarkan pekerjaan yang tumpang tindih, menjamin usaha dan sumber penghasilan serta keseimbangan keseluruhan organisasi. Sutisna (1985:46) menjelaskan bahwa koordinasi ialah proses mempersatukan sumbangan-sumbangan dari orang-orang, bahan dan sumber-sumber lain ke arah tercapainya maksud-maksud yang telah ditetapkan.

Berdasarkan pendapat di atas menurut hemat penulis bahwa koordinasi adalah proses menyatukan tindakan dari berbagai orang atau bidang dalam organisasi untuk mencapai tujuan organisasi. Jadi kegiatan koordinasi ada pada berbagai fungsi manajemen dan menyertai tindakan semua orang yang terkait untuk mencapai tujuan tertentu dari suatu kegiatan.

Wewenang atau kekuasaan dapat pula disebut sebagai otoritas dalam Koswara (2002:23) diartikan dalam dua dimensi, yaitu formal dan penerimaan. Berdasarkan teori formal, wewenang merupakan anugerah karena seseorang diberi, dilimpahi atau diwarisi kekuasaan untuk mengatur sesuatu. Pandangan ini beranggapan bahwa otoritas berasal dari masyarakat tingkat tinggi dan secara hirarkis diturunkan sampai tingkat paling bawah.

Pandangan teori penerimaan berpendapat bahwa otoritas seseorang timbul bila diterima oleh kelompok atau lingkungannya. Kunci dasar wewenang adalah terletak pada orang- orang yang dapat dipengaruhi (influenced), bukan yang mempengaruhi (influences). Jadi wewenang itu tergantung pada penerimaan (receiver) yang memperoleh wewenang. Wewenang seseorang dapat diterima apabila empat kondisi dapat terpengaruh (Koswara, 2002:24), yaitu: (1) dapat memahami komunikasi lingkungannya, (2) pada saat keputusan dibuat dia percaya bahwa hal itu tidak menyimpang dari tujuan organisasi, (3) tidak bertentangan dengan kepentingan pribadi dan kelompok, dan (4) orang yang diberi wewenang mampu secara fisik dan mental untuk melaksanakannya.

\section{METODE PENELITIAN}

Lokasi penelitian ini dilakukan di Madrasah Aliyah Negeri (MAN) Kisaran beralamat di Jalan Latsitarda Nusantara VIII Kecamatan Kota Kisaran Timur Kabupaten Asahan Provinsi Sumatera Utara.

Metode penelitian menurut soehartono (2002:9) adalah cara atau strategi menyeluruh untuk menemukan atau memperoleh data yang diperlukan. Penelitian ini termasuk ke dalam penelitian deskriptif dengan metode kualitatif.

Metode kualitiatif adalah metode penelitian yang dipergunakan untuk meneliti pada kondisi objek yang alamiah, (sebagai lawannya adalah ekperimen) dimana peneliti adalah sebagai instrumen kunci, teknik pengumpulan data dilakukan secara triangulasi (gabungan), analisis data bersifat induktif, dan hasil penelitian kualitatif lebih menekankan makna dari pada generalisasi (Sugiono, 2008:1). Penelitian kualitatif ini memiliki objek yang alamiah sehingga sering disebut sebagai metode naturalistik. Objek yang alamiah maksudnya objek yang apa adanya, tidak dipengaruhi manipulasi dari peneliti sehingga keadaan saat penelitian memasuki, berada dan keluar dari objek relatif tidak mengalami perubahan. 
Populasi menurut Sugiyono (2008:80) adalah wilayah generalisasi yang terdiri atas obyek atau subyek kualitas dan karakteristik tertentu yang ditetapkan oleh peneliti untuk dipelajari dan kemudian ditarik kesimpulan. Sedangkan Suharsimi Arikunto (2006: 130), mengatakan "populasi merupakan keseluruhan dari subyek yang diteliti yakni semua elemen yang ada dalam penelitian. Oleh karena itu populasi dalam penelitian ini adalah seluruh pegawai, guru, dan siswa yang mengajar di MAN Kisaran. Sehubungan dengan hal tersebut, sampel dalam penelitian ini diarahkan pada pencarian data dari Kepala Seksi Pendidikan Madrasah Kantor Kementerian Agama Kabupaten Asahan, Tata Usaha MAN Kisaran, Guru dan Siswa MAN Kisaran. Pencarian data dimulai dari pimpinan dalam hal ini Kepala Seksi Pendidikan Madrasah sebagai informan kunci (key informant) dengan menggunakan purposive sampling.

Dalam metode penelitian kualitatif, peneliti merupakan instrumen utama (key instrument). Hakikat peneliti sebagai instrumen kunci diaplikasikan dalam penggunaan teknik pengumpulan data kualitatif yang terdiri dari; wawancara, observasi dan dokumen (catatan atau arsip).

Dalam penelitian kualitatif analisis data secara umum dibagi menjadi tiga tingkat; analisis pada tingkat awal, analisis pada saat pengumpulan data lapangan, dan analisis setelah selesai pengumpulan data (Huberman \& Miles, 1994).

Penyajian data dilakukan setelah proses reduksi. Penyajian data dapat dilakukan melalui uraian singkat, bagan, table, flowchart dan sejenisnya. Menurut Miles dan Huberman (1992) penyajian data merupakan proses pemberian sekumpulan informasi yang sudah disusun yang memungkinkan untuk penarikan kesimpulan. Proses penyajian data ini adalah mengungkapkan secara keseluruhan dari sekelompok data yang diperoleh agar mudah dibaca.

\section{HASIL DAN PEMBAHASAN}

Pola kepemimpinan diartikan sebagai suatu cara penampilan karakteristik atau tersendiri. Menurut Follet dalam Nursalam (2007), pola didefinisikan sebagai hak istimewa yang tersendiri dari ahli dengan hasil akhir yang dicapai tanpa menimbulkan isu sampingan. Sedangkan Gilles dalam Nursalam (2007) menyatakan bahwa pola kepemimpinan dapat diidentifikasi berdasarkan perilaku pemimpin itu sendiri. Perilaku seseorang dipengaruhi oleh adanya pengalaman bertahun-tahun dan lama dalam kehidupannya. Oleh karena itu, kepribadian seseorang akan mempengaruhi pola kepemimpinan yang digunakan.

Pola kepemimpinan adalah cara pemimpin dalam membawa dirinya sebagai pemimpin, cara berlagak dalam menggunakan kekuasaannya, misalnya pola kepemimpinan otoriter, demokratis, paternalistik (Rachmansyah, 2008). Pola kepemimpinan seseorang cenderung sangat bervariasi dan berbeda-beda. Berdasarkan hasil pengamatan dilapangan, ditemukan pola kepemimpinan Kepala MAN Kisaran dalam melaksanakan tugas dan memimpin seluruh aktivitas madrasah untuk mencapai visi, misi dan tujuan MAN Kisaran serta terselenggaranya kegiatan pendidikan telah berjalan dengan baik dan sebagaimana mestinya. Kepemimpinan Kepala MAN Kisaran dalam melaksanakan tugas perkerjaannya, diketahui mempedomani dan mengacu kepada Peraturan Menteri Agama Nomor 29 Tahun 2014 tentang 
Qurrota A'yuni, Pola Kepemimpinan Kepala Madrasah Aliyah Negeri Kisaran dalam

Kepala Madrasah. Kewenangan dan tanggung jawab Kepala MAN Kisaran tersebut diantaranya: 1) Menetapkan dan mengembangkan kurikulum di madrasah; b) Menetapkan rencana kerja tahunan yang merupakan penjabaran rinci dari rencana kerja jangka menengah madrasah untuk masa 4 tahun; c) Menetapkan kebijakan teknis terkait efektifitas pengelolaan madrasah sesuai dengan ketentuan perundang-undangan; d) Menetapkan pembagian tugas dan pendayagunaan guru dan tenaga kependidikan pada madrasah; e) Menerbitkan ijazah/Surat tanda Tamat Belajar, Surat keterangan Pengganti Ijazah yang berpenghargaan sama dengan ijazah/Surat Tanda Tamat Belajar dan dokumen akademik lainnya sesuai dengan ketentuan perundang-undangan; f) Melakukan penilaian prestasi kerja guru dan tenaga administrasi kependidikan PNS dan penilaian kerja Guru PNS bagi kepala madrasah PNS dan; g) Melakukan penilaian kinerja Guru dan tenaga kependidikan nonPNS.

Peran kepemimpinan Kepala MAN Kisaran dalam melaksanakan tugastugasnya tersebut sebagai seorang pemimpin yaitu: a) Ketatalaksanaan, yaitu membuat kebijakan, menata, mengatur pelaksanaan, dan membuat keputusan untuk mengelola madrasah, dan kegiatan pendidikan. Misalnya mengelola sumber daya seperti: wakil kepala madrasah, kepala tata usaha, guru, staf, dan siswa, b) Pengendaliaan, yaitu mengendalikan situasi atau kondisi (control) atas semua kegiatan program dan komponen penyelenggaraan pendidikan pada madrasah. Misalnya penghimpunan kurikulum, bahan pustaka, proses pengolahan, pemberian layanan, kerjasama dan pengembangan guru dan staf.
C) Pembinaan, yaitu yang bersifat pengembangan semangat, kemampuan, keterampilan, keahlian, dan tertib organisasi.

Berdasarkan wawancara penulis kepada bapak Taufik, S.Ag. MA. jabatan sebagai Kaur Tata Usaha MAN Kisaran yang dilakukan pada tanggal 31 Mei 2017, terkait dengan pola kepemimpinan kepala MAN Kisaran dengan kutipan sebagai berikut:

"...Pola kepemimpinan kepala madrasah dalam melaksanakan pekerjaannya, bahwasanya beliau memiliki figur yang ramah, beretika dan santun dalam berkomunikasi. beliau juga mau mendengar pendapat orang dan tidak otoriter, tidak membuat keputusan sendiri..."

Kemudian hal senada juga di sampaikan oleh Ibu Dewiana Umriah Pulungan, S.Ag selaku Wakil Kurikulum MAN Kisaran, melalui wawancara yang dilakukan pada tanggal 31 Mei 2017, beliau mengatakan dengan kutipan sebagai berikut:

“...Pola kepemimpinan Kepala MAN Kisaran dalam melaksanakan tugas bersifat low profil dan tidak otoriter, beliau mengajak berdiskusi dan selalu bermusyawarah, bekerjasama untuk menyatukan persepsi yang berbeda dan beliau juga memberi masukan dengan aturan yang ada dengan memberi pandangan dan akibatnya dengan netral dan tidak memihak".

Sehubungan dengan hal tersebut, penulis juga mewawancarai Ibu Ellya Panjous SN, M.Pkim selaku wakil kesiswaan MAN Kisaran. Menurut Ibu Ellya Panjous SN, M.Pkim, melalui wawancara yang dilakukan pada tanggal 31 Mei 2017, beliau berpendapat terhadap pola kepemimpinan Kepala MAN Kisaran dalam melaksanakan pekerjaan sebagaimana kutipan berikut: 
“...Pola kepemimpinan Kepala MAN Kisaran, beliau mau mendengarkan inspirasi dan masukan dari pegawainya dan memusyawarahkan hasilnya demi mewujudkan kesepakatan bersama.

Selanjutnya menurut Bapak Erwin Chandra S.Pd wakil sarana prasarana MAN Kisaran, beliau menyatakan dalam kutipan sebagai berikut:

“...Pola kepemimpinan kepala MAN Kisaran dalam melaksanakan tugas cenderung dengan mengajak bermusyawarah contohnya melalui briefing, dan rapat-rapat kecil..."

Kemudian penulis juga mewawancarai Ade Arianti Hasibuan, yang merupakan siswi kelas XII-IPA 1 MAN Kisaran, Ade Arianti Hasibuan berpendapat sebagaimana kutipan berikut:

“...Pola kepemimpinan kepala MAN Kisaran dalam memimpin upacara apel pagi, bahwasanya kepala MAN tegas dan selalu mengarahkan supaya siswa/i lebih giat belajar dan meningkatkan mutu pendidikan ke jenjang yang lebih tinggi, dan beliau juga sering menekankan kedisplinan. Beliau juga sering memotivasi siswa/i untuk melaksanakan puasa senin-kamis (PUSAKA) dan sholat dhuha. Demi mewujudkan madrasah lebih baik dan lebih baik madrasah..."

Hasil yang dapat disimpulkan penulis terkait dengan pola kepemimpinan kepala MAN Kisaran dari beberapa pengamatan dan wawancara tersebut, kepala MAN Kisaran telah menjalankan beberapa fungsi kepemimpinan dengan baik. Para pegawai, guru dan siswa merasa puas dengan kepemimpinan kepala MAN, bahwa beliau telah menjalankan beberapa fungsi kepemimpinan yakni menciptakan kebersamaan diantara wakil, guru, pegawai dan siswa melalui mengambil keputusan berdasarkan musyawarah dan mufakat. Kemudian kepala MAN Kisaran juga selalu menerima masukan, saran, inspirasi dari bawahannya. Sebagian besar guru mengatakan bahwa kepala sekolah telah menciptakan kebersamaan diantara guru, pegawai dan siswa yaitu melalui kegiatankegiatan rutin yang dilaksanakan di MAN Kisaran. Kepala MAN Kisaran menciptakan kebersamaan pada setiap hari, pertengahan semester dan diakhir semester. Tujuannya adalah agar guru dan pegawai selalu terbangun motivasi, dan mendapat pencerahan. Menciptakan kebersamaan didalam madrasah sangat dibutuhkan, hal ini memerlukan kegiatan khusus agar terciptanya kebersamaan di antara guruguru. Maka dari itu kepala MAN Kisaran sangat konsisten membangun kebersamaan diantaranya. Akan tetapi, suasana kebersamaan tersebut tidak begitu signifikan dalam mempengaruhi kualitas dan kinerja pegawai. Suasana kebersamaan tersebut malah membuat pegawai dan guru tidak takut, segan dan loyal kepada pimpinan. Hal ini dapat dilihat dari pegawai yang masih senang menumpuk pekerjaan dan mengulur-ulur waktu kerja.

Sehubungan dengan hal tersebut, dapat di simpulkan bahwa pola kepemimpinan kepala MAN Kisaran dalam membuat suatu kebijakan dan keputusan yang akan di laksanakan oleh para wakil, guru, pegawai dan sebagainya. Keputusan tersebut berdasarkan hasil musyawarah dan mufakat yang memenuhi kriteria aspiratif, yaitu prosesnya melibatkan bawahan, waktu tepat, dan mampu memecahkan masalah secara musyawarah, 
sehingga suatu program dan kegiatan dapat dilaksanakan dengan baik.

Dari hasil observasi dan wawancara tersebut, mengenai pola kepemimpinan kepala MAN Kisaran dapat disimpulkan bahwa pola kepemimpinan kepala MAN Kisaran bersifat demokratif dan partisipatif, artinya menampung aspirasi bawahannya, merembukkan secara bersama-sama dan memutus secara musyawarah dan mufakat. Pola kepemimpinan kepala MAN Kisaran tidak otoriter, memaksakan kehendak dan dalam memutus tidak bersifat sepihak. Menurut Hersey (2002:14) bahwa ada 4 perilaku pimpinan antara lain: perilaku memberitahukan (telling), perilaku menjual (selling), perilaku berperan serta (partisipatif), dan perilaku mendelegasikan (delegating).

Pola kepemimpinan Kepala MAN Kisaran dalam melaksanakan pekerjaan sesuai dengan perilaku pimpinan yang berperan serta (partisipatif). Bahwa perilaku pimpinan berperan serta (partisipatif) merupakan unsur penting yang dilakukan oleh pimpinan dalam suatu lembaga atau organisasi, dalam pemberdayaan keikutsertaan anggota dalam menentukan suatu kebijakan dari suatu permasalahan merupakan hal perlu dipertimbangkan oleh pimpinan. Dalam hal pimpinan dan pengikut bersama-sama mengambil keputusan dengan peran utama dari pemimpin adalah mempermudah dan komunikasi. (orientasi tugas rendah hubungan tinggi). Perilaku pimpinan ini dimana pemimpin membangun suatu hubungan dengan karyawannya secara bersamaan.

Hal ini juga dikemukakan oleh Hersey dkk dalam Robbins (2002:14) yang menjelaskan bahwa pemimpin dan pengikut bersama-sama mengambil keputusan dengan peran utama dari pemimpin adalah mempermudah dan berkomunikasi. Maksudnya membagi proses pembuatan keputusan dan pemecahan dengan anak buahnya, dalam menyelesaikan suatu tugas. Selain itu Thoha (2000:260) mengatakan bahwa kepemimpinan partisipatif dimana gaya kepemimpinan, pemimpin berusaha meminta dan mempergunakan saran-saran dari bawahannya, namun pengambilan keputusan tetap berada padanya. Selanjutnya Likert dalam Thoha (2009:270) berpendapat bahwa pemimpin partisipatif dalam hal ini pemimpin mempunyai kepercayaan yang sempurna terhadap bawahannya.

Stoner (1996:67) mengatakan bahwa Pendelegasian wewenang adalah pemberian kekuasaan/otoritas formal dan tanggung jawab untuk melaksanakan kegiatan tertentu kepada orang lain. Selanjutnya Siswanto (1987:34) mengemukakan bahwa pendelegasian wewenang otoritas dan tanggungjawab dari pimpinan kepada seseorang untuk melaksanakan aktivitas tertentu.

Dari definisi pendelegasian wewenang yang dikemukakan di atas dapat disimpulkan bahwa pendelegasian wewenang itu merupakan penyerahan otoritas/kekuasaan dari pimpinan kepada bawahan agar tugas dan tanggungjawab dapat dilaksanakan dengan baik. Pembagian tugas dan wewenang bagi seluruh anggotanya akan sangat bermanfaat bagi manajemen organisasi apabila manajer dapat memanfaatkan orientasinya dengan baik.

Sehubungan dengan hal tersebut, bahwa berdasarkan wawancara yang dilakukan oleh penulis pada tanggal $31 \mathrm{Mei}$ 
2017 kepada Bapak Taufiq, S.Ag. MA. yang merupakan Kaur Tata Usaha MAN Kisaran. Beliau berpendapat terkait dengan pola kepemimpinan kepala MAN dalam melaksanakan pendelegasian wewenang sebagaimana kutipan berikut:

“...Pola Kepemimpinan Kepala MAN Kisaran dalam melaksanakan pendelegasian wewenang, beliau memerintahkan Kaur Tata Usaha untuk mengkonsep pembagian tugas pegawai pendidik dan kependidikan madrasah, selanjutnya diperiksa dan disetujui oleh beliau..."

Kemudian menurut Ibu Dewiana Umriah Pulungan, S.Ag Wakil Kurikulum. Beliau mengatakan sebagai berikut:

“...Pola kepemimpinan kepala MAN dalam melaksanakan pendelegasian wewenang, bahwa beliau telah membagi tupoksi masing-masing sesuai dengan bidangnya, tetapi beliau juga memberi arahan untuk saling membantu dan kerjasama di samping tupoksi yang ada..."

Selanjutnya menurut Erwin Chandra, S.Pd. Wakil Sarana Prasarana melalui wawancara pada tanggal 31 Mei 2017, beliau berpendapat dalam kutipan sebagai berikut:

“...Bahwasanya pola kepemimpinan kepala MAN Kisaran dalam melaksanakan pendelegasian wewenang, beliau membagi tugas sesuai dengan bidangnya masingmasing dan beliau tidak diskriminasi antara guru dan satu lainnya. Kemudian bila ada masalah di minimalisir dan diselesaikan secara kekeluargaan..."

Hal senada juga disampaikan oleh Ibu Ellya Panjous, M.Pkim. Wakil Kesiswaan. Melalui wawancara yang dilakukan pada tanggal 31 Mei 2017, Ibu Ellya Panjous,
M.Pkim berpendapat sebagaimana dalam kutipan berikut:

“...Pola Kepemimpinan kepala MAN Kisaran dala melaksanakan tugas pendelagasian wewenang, bahwa beliau adil dan merata dalam membagi tupoksi dan bidang tugas masing-masing serta tetap saling membantu dalam pelaksanaan tugas..."

Berdasarkan beberapa pendapat melalui wawancara yang dilakukan, penulis menyimpulkan bahwa pola kepemimpinan Kepala MAN Kisaran dalam pendelegasian wewenang bersikap adil, tidak diskriminatif dan membagi tugasnya sesuai dengan bidang masing-masing. Sejalan dengan hal tersebut, mengutip pendapat Hersey dkk dalam Robbins (2002:14) yang mengemukakan bahwa perilaku pendelegasian pemimpin merupakan suatu hal penting yang perlu dilakukan pimpinan dalam meningkatkan pemberdayaan dalam suatu organisasi atau lembaga tertentu. Pemimpin memberikan sedikit pengarahan dan dukungan. Ini akan berakibat (orientasi tugas rendah- hubungan rendah) yaitu memberi tanggungjawab dalam pembuatan keputusan dan pemecahan masalah kepada bawahannya. Artinya pendelegasian akan rendah hasilnya apabila dukungan dalam tugas yang diberikan pimpinan rendah namun sebaliknya, jika dukungan tugas yang diberikan pimpinan tinggi akan menghasilkan pendelegasian yang tinggi. Selanjutnya Thoha (2000:281) mengemukakan bahwa pemimpin yang rendah dukungan dan rendah pengarahan disebut delegasi, karena pemimpin mendiskusikan masalah bersama-sama dengan bawahan sehingga tercapai kesepakatan mengenai definisi masalah 
Qurrota A'yuni, Pola Kepemimpinan Kepala Madrasah Aliyah Negeri Kisaran dalam

yang kemudian proses pembuatan keputusan didelegasikan secara keseluruhan kepada bawahan.

Selain itu, Kepala MAN Kisaran juga mengarahkan agar saling bekerja sama dalam menyelesaikan pekerjaan disamping tugas bidang masing-masing yang telah ada. Hal ini akan berpotensi menyebabkan tumpah tindih suatu pekerjaan, adanya pihak yang lepas tanggungjawab dari tugasnya sehingga akhirnya tidak tahu siapa yang harus bertanggung jawab atas pekerjaan tersebut. Kemudian hasil observasi yang penulis temukan di dalam rapat antara guru, pegawai dan lain-lain. Penulis melihat yang pada setiap dilaksanakannya rapat, kelengkapan dokumen lain seperti notulensi yang mencatat berita acara penyusunan RAPBS MAN Kisaran, masih dibuat secara manual dengan menggunakan tulisan tangan. Hal tersebut menunjukkan kekurangsiapan dan kekurangrapian pegawai administrasi di MAN Kisaran, karena notulensi sendiri dapat dibuat secara rapi dengan menggunakan personal computer (PC). Belum sepenuhnya melaksanakan aspek tugas pembagian wewenang dan tanggung jawab dalam melaksanakan pekerjaan misalnya notulensi yang dibuat menggunakan komputer. Walaupun dalam prosesnya dilaksanakan, tetapi kelengkapan dalam pembagian tugas masih banyak kekurangan.

Sebagai pimpinan, Kepala MAN Kisaran di Kabupaten Asahan berusaha mempengaruhi para wakil, pegawai dan guru dalam melakukan pekerjaannya sesuai bidang kerja. Dengan otoritas, keteladanan, pembagian kerja, dan keterampilan komunikasi interpersonal kepala mendorong berjalannya aktivitas, pembinaan, ketatausahaan, keuangan dan hubungan dengan masyarakat yang terkait dengan pencapaian tujuan. Dalam proses pengorganisasian, Kepala MAN Kisaran melakukan koordinasi dengan wakil, guru dan pegawai agar semua kegiatan lancar. Koordinasi di kantor seperti halnya dalam organisasi lain penting karena ada sejumlah jabatan, kedudukan, wewenang dan tanggung jawab sesuai struktur yang ada. Strukturisasi dalam organisasi adalah dalam rangka membagi tugas-tugas sesuai bidang yang diperlukan untuk mencapai tujuan organisasi. Dengan adanya bidang-bidang yang masing-masing memiliki tugas dan tanggung jawab sesuai jabatan yang ada merupakan suatu tindakan manajemen yang secara organisatoris perlu mendapat perhatian setiap pimpinan.

Kepala MAN Kisaran menandai seorang koordinator, pengetahuan, dan kesanggupankesanggupan dan dia akan berusaha bagi pengembangan dan kemajuan seluruh program (Sutisna, 1985:49). Untuk mencapai sinkronisasi dan integritas pelaksanaan tugastugas inilah maka diperlukan suatu koordinasi dari kepala sesuai otonominya terhadap semua staf, bidang atau bagian baik pembinaan pegawaian, pembiayaan, keuangan, sarana dan prasarana serta hubungan dengan masyarakat.

Semua itu diarahkan kepada pencapaian tindakan yang selaras, serasi dan sejalan dalam mencapai tujuan organisasi. Para pegawai akan terhindar dari kesimpangsiuran dan tumpang tindih dalam tugas-tugas dalam setiap kegiatan yang dilaksanakan. Demikian pula di kalangan para pegawai dan guru juga harus ada keselarasan tindakan dalam melakukan suatu kegiatan untuk mencapai tujuan organisasi. Sehubungan dengan hal tersebut, melalui wawancara yang telah dilakukan penulis pada tanggal 30 Mei 2017 kepada Ibu Suwastati Sagala, S.Ag. M.si selaku Kepala Seksi Pendidikan Madrasah Kabupaten Asahan. Menurut Ibu Suwastati Sagala, S.Ag. M.si pola kepemimpinan Kepala MAN dalam koordinasi kerja sebagaimana dalam kutipan berikut: 
“...Pola kepemimpinan kepala MAN Kisaran dalam melaksanakan koordinasi kerja, bahwa beliau dapat diajak bekerja sama dalam meningkatkan mutu pendidikan dan beliau juga selalu berkoordinasi ke bidang pendidikan madrasah untuk mengevaluasi kinerja pegawainya, guru, siswa dan madrasah agar menjadi lebih baik. Kemudian beliau juga sering meminta informasi ke bidang pendidikan madrasah mengenai peraturan, surat edaran terkait tentang pendidikan madrasah..."

Kemudian penulis juga melakukan wawancara di MAN Kisaran kepada Bapak Taufiq, S.Ag. MA. yang merupakan Kaur Tata Usaha MAN Kisaran pada tanggal 31 Mei 2017. Beliau berpendapat terkait dengan pola kepemimpinan kepala MAN dalam melaksanakan koordinasi kerja sebagaimana kutipan berikut:

“...Pola kepemimpinan kepala MAN Kisaran dalam melaksanakan koordinasi, menjalin kerjasama yang baik terhadap instansi terkait di dalamnya dan mencari informasi di lapangan untuk mewujudkan madrasah yang baik. Kemudian beliau tetap menjalin hubungan harmonis dan kekeluargaan dan belum ada kontra dengan instansi lainnya..."

Hal sejalan juga disampaikan oleh Ibu Dewiana Umriah Pulungan, S.Ag. Menurut Ibu Dewiana Umriah Pulungan, S.Ag Wakil Kurikulum. Beliau mengatakan sebagai berikut:

“...Menjalin hubungan horizontal dengan baik sesuai dengan standar yang ada, sedangkan secara vertikalnya beliau selalu aktif dalam menghadiri rapat eksternal misalnya menghadiri undangan di kementerian Agama Kab Asahan, dinas pendidikan Kab. Asahan dan SMA Negeri lainnya..."
Selanjutnya menurut Bapak Erwin Chandra, S.Pd. Wakil Sarana Prasarana melalui wawancara pada tanggal 31 Mei 2017, beliau berpendapat dalam kutipan sebagai berikut:

“...Tetap menjalin hubungan kerjasama yang baik, dan jika beliau berhalangan, beliau mewakilkan kepada wakil yang sesuai dengan bidang terkait. Kemudian ketika beliau menghadiri rapat eksternal, hasil rapat tersebut kemudian di sosialisakan dalam rapat internal..."

Selain itu, penulis juga melakukan wawancara kepada Ibu Ellya Panjous, M.Pkim pada tanggal 31 Mei 2017. Sebagaimana yang disampaikan oleh Ibu Ellya Panjous, M.Pkim. yang merupakan sebagai Wakil Kesiswaan. Beliau berpendapat terkait pola kepemimpinan Kepala MAN dalam koordinasi kerja sebagai berikut:

“...Beliau proaktif dalam menghadiri rapat keluar dan kemudian mengaplikasikan hasil rapat tersebut di madrasah dengan melibatkan bidang-bidang pendukung untuk melaksanakan pekerjaan ...".

Berdasarkan hasil wawancara dan observasi yang dilakukan, penulis menyimpulkan bahwa pola kepemimpinan kepala MAN dalam hal koordinasi kerja terjalin cukup baik. Secara vertikal, hubungan kerja Kepala MAN Kisaran dengan Kepala Seksi Pendidikan Madrasah Kabupaten Asahan terjalin hubungan kerjasama yang baik secara integrasi dan terpadu. Setiap ada kegiatan yang diselenggarakan oleh kantor Kementerian Agama Kabupaten Asahan bagian Pendidikan Madrasah, Kepala MAN selalu menghadiri undangan dan proaktif untuk meminta informasi-informasi terkait dengan peraturan dan peningkatan mutu pendidikan madrasah. Begitu juga secara 
Qurrota A'yuni, Pola Kepemimpinan Kepala Madrasah Aliyah Negeri Kisaran dalam

horizontal, Kepala MAN Kisaran selalu aktif memberitahukan atau memberikan informasi terbaru dan mensosialisasikan kepada wakil, guru dan pegawai di dalam rapat internal. Informasi tersebut yang diperoleh dari luar senantiasa di aplikasikan di dalam madrasah, sehingga para wakil, guru, dan pegawai mengetahui informasi terbaru. Selain itu, Kepala MAN Kisaran selalu menghunjuk wakil yang terkait untuk menghadiri rapat atau pertemuan di luar bila jadwal kerjanya berbenturan di waktu yang bersamaan. Berdasarkan hal tersebut, Menurut Hersey (2002:14) bahwa perilaku pimpinan yang memberitahukan (telling) adalah cara yang dilakukan pimpinan dalam pemberdayaan, hal ini dapat memberikan hasil yang efektif. Perilaku memberitahukan merupakan proses mempengaruhi kegiatan orang lain menuju pada pencapaian sasaran. Memberitahukan merupakan bagian dari perilaku pimpinan. Untuk itu pemimpin harus dapat mendefenisikan peran dan memberitahukan kepada orang-orangnya apa, bagaimana, kapan dan dimana berbagai tugas harus dilakukan. Perilaku ini menekankan pada pengarahan (direktif).

\section{SIMPULAN}

Pola kepemimpinan kepala MAN Kisaran dalam pelaksanaan pekerjaan secara demokratif dan partisipatif, artinya perilaku pimpinan tersebut tidak otoriter, mau menerima masukan dari pegawainya, mengajak berdiskusi dan membuat keputusan secara musyawarah. Pola kepemimpinan Kepala MAN Kisaran dalam pelaksanaan pendelegasian wewenang telah berjalan sebagaimana mestinya, pembagian tugas dan kerja pegawai tersebut dilakukan secara adil, tidak diskriminatif dan membagi tugasnya sesuai dengan bidang masing- masing serta mengarahkan agar saling bekerja sama dalam menyelesaikan pekerjaan disamping tugas yang telah ada masing-masing. Pola kepemimpinan kepala MAN dalam hal koordinasi kerja terjalin cukup baik, secara vertikal hubungan kerja Kepala MAN Kisaran dengan Kepala Seksi Pendidikan Madrasah Kabupaten Asahan terjalin hubungan kerjasama yang baik, terintegrasi dan terpadu, secara horizontal Kepala MAN Kisaran selalu aktif memberikan informasi terbaru dan mensosialisasikan kepada wakil, guru dan pegawai di dalam rapat internal.

\section{DAFTAR PUSTAKA}

Arikunto, S. 2002. Prosedur Penelitian Suatu Pendekatan Praktek. Edisi Revisi V. Jakarta: Penerbit PT Rineka Cipta.

Ban, C. 1995. How Do Public Managers Manage? San Francisco: JosseyBass Publishers.

Barata, A.A.. 2003. Dasar-dasar Pelayanan Prima. Jakarta: Gramedia.

Burhanuddin, 2004. Gaya Kepemimpinan Ideal, Bandung: Press.

Dimock, M.E.. 1986. Administrasi Negara.Jakarta: Erlangga.

Holland. 1993. Public Sector Management. New York: Harvester Wheatsheaf.

Hall. E., 2002. Leadership Theoery. Belmont: Wadsworth/thomson Learning.

Handoko, 1997. Sukses Kepemimpinan, Surabaya: Erlangga.

Hersey and Robbins, 2002, Leadership, New York: Bringham University.

Kartasasmita, G.. 1997. Administrasi Pembangunan. Jakarta: $\mathrm{LP}_{3} \mathrm{ES}$.

Koontz, 2001, Leadership is Influence People to Follow Individu. New York: Harvard University

Lovelock, C., 2002. Services Marketing in Asia: Managing People, Technology and Strategy. New Delhi: Prentice Hall.

McKevitt, D; Alan L., 1994. Public Sector Management. London: Sage.

Muhadjir, D., 2001. Analisis Kebijakan Publik. Yogyakarta: Hanindita Graha Widia.

Nasir, M.. 1988. Metode Penelitian. Jakarta: Ghalia Indonesia.

Nursalam, 2007. Pola Kepemimpinan Mentransformasikan Semangat Wirausaha ke Dalam Sektor Publik (Reinventing 
Government - How The Enterpreneurship Spirit in Transforming the public Sector). Jakarta: PPM.

Osborne, D dan Peter P., 1996. Banishing Bureaucrachy: The Five Strategies For Reinventing Government. Reading, Massachusetts: AddisonWesley.

Parasuraman, A., Zeithalm, V., dan Berry L. 1988. Servqual: A Multiple item Scale for Measuring Consumer Perceptions of Service Quality. Journal of Retaliling.

Rachamnsyah, 2008. Kepemimpinan Otoriter, Demokratis dan Paternalistik, Jakarta: Sinar Grafika.

Sutisna, 2002. Manajemen Birokrasi. Jakarta: Elek Media Komputindo.

Sutarto, 2008. Pembagian Wewenang. Jakarta: Sinar Grafika.

Sekaran, U., 2006. Research Methods For Business. Jakarta: Salemba Empat.

Simon, H.A.. 1962. Public Administration: Administrative Behavior. New York: Macmillan.

Siswanto. 1987. Pendelegasian Wewenang Publik. Semarang: Tiga Serangkai.

Sugiono. 2008. Metode Penelitian. Jakarta: Persada.

Sugiarto. 2003. Teknik Sampling. Jakarta: PT. Gramedia Pusta Utama.

Thoha. 200o. Kepemimpinan Partisipatif. Jakarta: Grafindo

Tjiptono, F., dan Gregorius C., 2005. Service, Quality, and Satisfaction. Yogyakarta: Andi Offset.

Wahyosumidjo, 1999. Perilaku Pimpinan dalam Manajemen, Jakarta: Kencana 